\title{
PENGARUH IKLIM KELAS, SIKAP SISWA, DAN MOTIVASI BELAJAR TERHADAP HASIL BELAJAR MATEMATIKA SISWA KELAS VIII SMP NEGERI DI KOTA PALU
}

\author{
Hajerina \\ Program Studi Pendidikan Matematika FKIP UNISA, \\ Jl. Karajalembah No. 37 Palu
}

\begin{abstract}
ABSTRAK
Penelitian ini bertujuan untuk mengetahui gambaran dan pengaruh iklim kelas matematika terhadap hasil belajar matematika siswa kelas VIII SMP Negeri di kota Palu.Jenis penelitian ini adalah ex-post facto yang bersifat kausalitas. Sampel dalam penelitian ini adalah siswa Kelas VIII SMP Negeri di Kota Palu tahun pelajaran 2013/2014 yang diambil dengan menggunakan tehnik two-stage proporsional stratified random sampling yang berjumlah 198 siswa. Instrumen yang digunakan: (1) skala iklim kelas matematika, (2) skala sikap terhadap matematika, (3) skala motivasi belajar matematika, (4) tes hasil belajar matematika kelas VIII. Data dianalisis dengan statistik deskriptif dan analisis jalur (path anlysis). Hasil Penelitian menunjukkan bahwa: Iklim kelas matematika berpengaruh secara signifikan terhadap hasil belajar matematika siswa baik secara langsung maupun tidak langsung melalui sikap siswa dan motivasi belajar siswa dengan besar pengaruh masing - masing 0,16 dan 0,20.
\end{abstract}

Kata Kunci: Hasil belajar, iklim kelas, sikap siswa, dan motivasi belajar

\begin{abstract}
The study aims at discovering the influence of classroom climate toward mathematics learning result of grade VIII students at SMPN in Palu. The study is an ex-post facto with causality. The sample of the study was grade VIII students at SMPN in Palu of academic year 2013/2014 taken by employing two-stage proportional stratified random sampling technique which amounts to 198 students. The instruments used in the study were (1) scale of mathematics classroom climate, (2) scale of attitude towards mathematics, (3) scale of mathematics learning motivation, and (4) test of learning result of mathematics of grade VIII. Data were analyzed by employing statistics descriptive and path analysis. The result of the study reveal that classroom climate of mathematics give significant influence toward students' learning result both directly and indirectly through students' attitude and students' learning motivation with each of the influence 2,78\% and 1,46\%.
\end{abstract}

Key Word: Learning result, classroom climate, students attitude, and learning motivation. 


\section{Pendahuluan}

Rendahnya hasil belajar matematika siswa di Indonesia khususnya di kota Palu dipengaruhi oleh banyak faktor, baik faktor yang berasal dari dalam diri peserta didik (faktor internal) yang meliputi keadaan jasmani, kecerdasan/intelegensi, motivasi, minat, sikap, dan bakat, maupun faktor yang berasal dari luar peserta didik (faktor eksternal) yang meliputi lingkungan sosial sekolah, lingkungan sosial masyarakat, lingkungan sosial keluarga, lingkungan alamiah, metode mengajar, kurikulum, disiplin sekolah serta sarana dan prasarana sekolah. Kedua faktor ini berpengaruh satu sama lain sehingga kedua-duanya haruslah mendapat perhatian agar peserta didik dapat belajar dengan baik (Baharuddin, 2007: 19)

Keberhasilan pembelajaran di sekolah, khususnya pada mata pelajaran matematika di tingkat SMP tidak cukup hanya dengan menilai hasil belajar siswa, namun perlu menilai proses belajar mengajar di dalam kelas. Hal ini perlu dilakukan karena dalam setiap kegiatan, hasil atau keberhasilan dari kegiatan tersebut selalu dipengaruhi oleh proses kegiatan itu sendiri, begitupun dalam proses pembelajaran.

Pada hakikatnya proses pembelajaran merupakan interaksi antara Pengaruh ... (Hajerina) guru dengan siswa, siswa dengan siswa, maupun siswa dengan sumber belajar lainnya yang terjadi dalam ruang kelas, sehingga kualitas pembelajaran akan bergantung pada perilaku guru dalam mengajar dan perilaku siswa dalam belajar di kelas yang merupakan refleksi dari sikap dan motivasi belajar. Hal ini menunjukkan bahwa suasana proses pembelajaran di kelas (iklim kelas) memiliki peranan yang penting dalam proses pembelajaran.

Iklim kelas yang kondusif merupakan bagian dari sekolah yang mempengaruhi sikap dan motivasi belajar siswa. Menurut Reilly dan Lewis (1983), Iklim kelas mengacu kepada berbagai dimensi psikologis dan sosial di dalam kelas, seperti tingkat formalitas, fleksibilitas, struktur, kecemasan, kontrol dari guru, aktivitas dan juga dorongan (Hadinata, 2009:94). Pada iklim kelas yang positif, siswa akan merasa nyaman ketika memasuki ruang kelas, mereka mengetahui bahwa akan ada yang memperdulikan dan menghargai mereka, dan mereka percaya bahwa akan mempelajari sesuatu yang berharga. Namun sebaliknya, pada iklim kelas negatif, siswa akan merasa takut apabila berada di dalam kelas dan ragu apakah mereka akan mendapat pengalaman yang berharga (Hadinata, 2009:94)

AdMathEdu | Vol.7 No.2 | Desember 2017 
Sejalan dengan pendapat di atas, Widoyoko (2012: 203) juga berpendapat bahwa iklim kelas yang baik akan mempunyai pengaruh terhadap sikap dan motivasi belajar siswa serta hasil belajar siswa. Sikap positif siswa dalam kegiatan pembelajaran akan mempunyai pengaruh terhadap motivasi dan hasil belajar siswa, sedangkan motivasi belajar siswa akan mempunyai pengaruh terhadap keberhasilan belajar.

Berdasarkan pemaparan di atas, maka dapat diasumsikan bahwa iklim kelas, sikap siswa, dan motivasi belajar merupakan empat variabel yang dapat mempengaruhi hasil belajar siswa. Oleh karena itu penulis tertarik untuk melakukan penelitian mengenai pengaruh fasilitas pembelajaran, iklim kelas, sikap siswa, dan motivasi belajar terhadap hasil belajar matematika siswa.

\section{Metode Penelitian}

Penelitian ini merupakan penelitian ex-post facto yang bersifat kausalitas. Adapun variabel-variabel yang diteliti yakni iklim kelas sebagai variabel bebas, sikap siswa dan motivasi belajar sebagai variabel intervening, dan hasil belajar sebagai variabel terikat. Populasi dalam penelitian ini adalah seluruh siswa SMP negeri kelas VIII di kota Palu, dengan jumkah sampel 198 siswa.
Pengumpulan data dilakukan dengan memberikan instrumen penelitian berupa skala iklim kelas, sikap siswa dan motivasi belajar siswa serta tes hasil belajar. Selanjutnya data hasil penelitian dianalisis dengan statistika deskriptif dan statistika inferensial yaitu analisis jalur (Path analysis).

\section{Hasil Dan Pembahasan}

\section{Hasil Analisis Statistika Deskriptif}

Untuk mengetahui deskripsi iklim kelas, sikap siswa, dan motivasi belajar siswa, serta hasil belajar siswa kelas VIII SMP negeri di Kota Palu, maka dilakukan analisis statistika deskriptif dengan bantuan SPSS sehingga diperoleh nilai rata-rata perolehan setiap siswa serta ukuran tendensi sentral lainnya. Dari hasil ini kemudian dilakukan pengelompokan menjadi 5 kategori, yakni sangat rendah, rendah, sedang, tinggi, dan sangat tinggi.

Berdasarkan analisis deskriptif di ketahui bahwa rata-rata skor iklim kelas siswa kelas VIII SMP Negeri di Kota Palu adalah 76,99 dari skor ideal 96 yang berarti berdasarkan kategori iklim kelas bahwa iklim kelas siswa saat proses pembelajaran matematika berada dalam kategori tinggi, rata-rata skor sikap siswa kelas VIII SMP Negeri di Kota Palu adalah 69,46 dari skor ideal 88 yang 
berarti berdasarkan kategori sikap siswa bahwa sikap siswa terhadap matematika berada dalam kategori tinggi, rata-rata skor motivasi belajar siswa kelas VIII SMP Negeri di Kota Palu adalah 94,41 dari skor ideal 120 yang berarti berdasarkan kategori motivasi belajar bahwa motivasi belajar siswa terhadap matematika berada dalam kategori tinggi, dan rata-rata skor motivasi belajar siswa kelas VIII SMP Negeri di Kota Palu adalah 51,28 dari skor ideal 100 yang berarti berdasarkan kategori hasil belajar siswa bahwa hasil belajar matematika siswa berada dalam kategori rendah.

\section{Hasil Analisis Inferensial}

Asumsi normalitas penting terutama untuk penarikan kesimpulan, berdasarkan analisis Uji Normalitas dan Linearitas dapat ditarik kesimpulan bahwa setiap variabel dalam analisis ini berdistribusi normal. Pada analisis Uji Normalitas dan Linearitas juga dapat dilihat hubungan keliniearan antar variabel. Dengan hubungan yang mengikuti garis lurus artinya persamaan regresi dapat digunakan untuk melakukan prediksi (prediction).

Berikut diagram analisis jalur ((Standardized Estimate) :

Pengaruh ... (Hajerina)

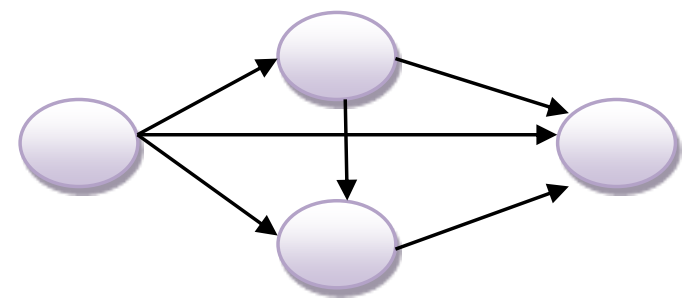

Gambar 1. Diagram analisis jalur

Keterangan : $\mathrm{X}$ : Iklim kelas dalam Pembelajaran Matematika

$\mathrm{Y}_{1}$ : Sikap Siswa terhadap Matematika

Y2: Motivasi Belajar Siswa terhadap Matematika

Y3: Hasil Belajar Matematika.

Berdasarkan analisis data diperoleh bahwa $X \quad$ berpengaruh signifikan terhadap $\mathrm{Y}_{1}$ dengan $\mathrm{p}<0,001$ $<0,05 . \quad Y_{1}$ berpengaruh signifikan terhadap $\mathrm{Y}_{2}$ dengan $\mathrm{p}<0,001<0,05$. $\mathrm{X}$ berpengaruh signifikan terhadap $\mathrm{Y}_{2}$ dengan $\mathrm{p}<0,001<0,05 . \mathrm{Y}_{1}$ berpengaruh signifikan terhadap $\mathrm{Y}_{3}$ dengan $p=0,019<0,05$. $Y_{2}$ berpengaruh signifikan terhadap $\mathrm{Y}_{3}$ dengan $\mathrm{p}=0,10<$ 0,05 . $X$ berpengaruh $Y_{3}$ dengan $p=0,41$ $<0,05$.

Selain nilai probabilitas, analisis juga menyajikan koefisien jalur terbakukan antar variabel-variabel, yaitu pengaruh iklim kelas (X) terhadap sikap siswa $\left(\mathrm{Y}_{1}\right)$ memiliki koefisien jalur sebesar 0,492. Pengaruh iklim kelas (X) terhadap motivasi belajar siswa $\left(\mathrm{Y}_{2}\right)$ memiliki koefisien jalur sebesar 0,24. Pengaruh sikap siswa $\left(\mathrm{Y}_{1}\right)$ terhadap motivasi belajar siswa $\left(\mathrm{Y}_{2}\right)$ memiliki AdMathEdu | Vol.7 No.2 | Desember 2017 
koefisien jalur sebesar 0,51. Pengaruh sikap siswa $\left(\mathrm{Y}_{1}\right)$ terhadap hasil belajar $\left(\mathrm{Y}_{3}\right)$ memiliki koefisien jalur sebesar 0,19 . Pengaruh motivasi belajar siswa $\left(\mathrm{Y}_{2}\right)$ terhadap hasil belajar $\left(\mathrm{Y}_{3}\right)$ memiliki koefisien jalur sebesar 0,21. Pengaruh iklim kelas (X) terhadap hasil belajar $\left(\mathrm{Y}_{3}\right)$ memiliki koefisien jalur sebesar 0,16 .

Selain pengaruh langsung antar variabel, diketahui juga besar pengaruh tidak langsung antar variabel yaitu besarnya pengaruh tidak langsung iklim kelas (X) terhadap motivasi belajar siswa $\left(\mathrm{Y}_{2}\right)$ adalah 0,25. Besarnya pengaruh tidak langsung iklim kelas (X) terhadap hasil belajar $\left(\mathrm{Y}_{3}\right)$ adalah 0,20. Besarnya pengaruh tidak langsung sikap siswa $\left(\mathrm{Y}_{1}\right)$ terhadap hasil belajar $\left(\mathrm{Y}_{3}\right)$ adalah 0,10 .

Berdasarkan hasil penelitian bahwa pada umumnya iklim kelas siswa kelas VIII SMP Negeri di Kota Palu termasuk dalam kategori tinggi. Hal ini memberikan gambaran bahwa iklim kelas siswa kelas VIII SMP Negeri di Kota Palu sudah kondusif.

Selanjutnya hasil penelitian juga menunjukkan bahwa sikap siswa kelas VIII SMP Negeri di Kota Palu terhadap matematika termasuk kategori tinggi. Hal ini memberikan gambaran bahwa sikap siswa kelas VIII SMP Negeri di Kota Palu terhadap matematika cukup positif. Hasil lainnya dalam penelitian ini yaitu mengenai motivasi belajar siswa yang menunjukkan bahwa motivasi belajar siswa kelas VIII SMP Negeri di Kota Palu pada umumnya termasuk dalam kategori tinggi. Hal ini memberikan gambaran bahwa motivasi belajar siswa kelas VIII SMP Negeri di Kota Palu sudah tinggi. Hal lain yang diungkap dalam penelitian ini yaitu bahwa pada umumnya hasil belajar matematika siswa Kelas VIII SMP Negeri di Kota Palu termasuk dalam kategori rendah. Hal ini memberikan gambaran bahwa hasil belajar matematika siswa kelas VIII SMP Negeri di Kota Palu masih rendah.

\section{Pengujian Hipotesis}

Hipotesis pertama bahwa iklim kelas (X) berpengaruh langsung dan signifikan terhadap hasil belajar $\left(\mathrm{Y}_{3}\right)$ matematika. Besarnya pengaruh iklim kelas $\left(\mathrm{X}_{2}\right)$ terhadap hasil belajar $\left(\mathrm{Y}_{3}\right)$ matematika yaitu 0,16 atau sebesar $(0,16)^{2}=2,5 \%$. Hasil penelitian ini sejalan dengan hasil penelitian yang dilakukan oleh Jan Bennett, B.M.E., M.E. (2001) dengan judul “ The Relationship Between Classroom Climate And Student Achievement". Hasil yang diperoleh pada penelitian yang dilakukan Bennet salah satunya adalah iklim kelas memiliki pengaruh terhadap prestasi belajar/hasil 
belajar siswa, meskipun tidak terlalu besar pengaruhnya.

Hipotesis kedua bahwa iklim kelas (X) berpengaruh secara tidak langsung dan signifikan terhadap hasil belajar kognitif $\left(\mathrm{Y}_{3}\right)$ melalui sikap siswa $\left(\mathrm{Y}_{1}\right)$, dengan besarnya pengaruh tidak langsung $(0,49)(0,19)=0,09$ atau sebesar $0,8 \%$. Hasil penelitian ini sejalan dengan pendapat Hoy dan Miskell (1982) yang mengatakan bahwa iklim kelas secara spontan mempengaruhi tingkah laku (Tarmidi, 2006), sedangkan menurut Rivera \& Ganaden (2001) tingkah laku atau sikap berhubungan dengan prestasi belajar atau hasil belajar siswa (Limpo, Oetomo \& Suprapto, 2013). Hal ini berarti iklim kelas yang kondusif akan merubah sikap siswa menjadi positif dan akan meningkatkan hasil belajar siswa.

Hipotesis ketiga bahwa iklim kelas (X) berpengaruh secara tidak langsung dan signifikan terhadap hasil belajar kognitif $\left(\mathrm{Y}_{3}\right)$ melalui motivasi belajar siswa $\left(\mathrm{Y}_{2}\right)$, dengan besarnya pengaruh tidak langsung $(0,25)(0,21)=$ 0,05 atau sebesar $0,27 \%$. Hasil penelitian ini sejalan dengan pendapat Kauchak dan Eggen (1997) yang mengatakan bahwa iklim kelas adalah hal yang penting karena menciptakan suatu lingkungan yang memberikan dorongan terhadap motivasi dan juga prestasi (Hadinata,
2009). Hal ini berarti iklim kelas yang kondusif akan memberikan motivasi kepada siswa untuk terus mengikuti kegiatan pembelajaran yang akan berdampak pada peningkatan hasil belajarnya. Semakin kondusif suatu iklim kelas, maka siswa akan semakin termotivasi untuk belajar dan akan memperoleh hasil yang meningkat, meskipun masih banyak faktor lain yang memperngaruhi tinggi rendahnya hasil belajar siswa.

Hipotesis keempat bahwa iklim kelas (X) berpengaruh secara tidak langsung dan signifikan terhadap hasil belajar kognitif $\left(\mathrm{Y}_{3}\right)$ melalui sikap siswa $\left(\mathrm{Y}_{1}\right)$ dan motivasi belajar siswa $\left(\mathrm{Y}_{2}\right)$, dengan besarnya pengaruh tidak langsung $(0,49)(0,51)(0,21)=0,05$ atau sebesar $0,28 \%$. Hasil penelitian ini sejalan dengan pendapat Cullingford (2003) yang mengatakan bahwa iklim kelas memiliki dampak yang besar terhadap sikap siswa dan motivasi belajar siswa (Kyriacou, 2007). Hal ini berarti, iklim kelas yang kondusif akan mempengaruhi sikap siswa terhadap pelajaran dan motivasi siswa untuk terus mengikuti kegiatan pembelajaran yang juga ikut mempengaruhi hasil belajar siswa. Hal ini menunjukkan bahwa semakin positif persepsi siswa terhadap iklim kelas, semakin positif pula sikap siswa terhadap 
matematika dan semakin tinggi pula motivasi belajar siswa, sehingga hasil belajar siswa akan semakin meningkat.

\section{Kesimpulan}

Berdasarkan hasil analisis data penelitian diperoleh kesimpulan dari hasil penelitian ini adalah iklim kelas siswa kelas VIII SMP Negeri di Kota Palu termasuk dalam kategori tinggi dengan rata - rata 76,99, Sikap siswa termasuk kategori tinggi dengan rata - rata 69,46 , motivasi belajar siswa termasuk kategori tinggi dengan rata - rata 94,41, dan hasil belajar siswa termasuk kategori rendah dengan rata - rata 51,28. Iklim kelas berpengaruh secara signifikan terhadap hasil belajar siswa baik secara langsung maupun tidak langsung dengan besar pengaruh masing - masing 0,16 dan 0,20.

\section{Pustaka}

Baharuddin. 2007. Teori Belajar \& Pembelajaran. Jogjakarta : ArRuzz Media.

Bennett, Jan. 2001. The Relationship Between Classroom Climate and Student Achievement. Dissertation. University Of North Texas

Chan, T. C. (1996). Environmental impact on student learning. http://eric.ed.gov/ERICWebPortal /Home.portal;jsessionid=HwnVG yBDgy9NhJG. Tanggal Akses 25 Mei 2014
Hadinata, P. (2009). Iklim kelas dan motivasi belajar siswa SMA. Jurnal Psikologi,3(1), 93-98.

Kyriacou, Chris. 2007. Essential Teaching Skills, Third Edition. London: Nelson Thomes Ltd

Limpo, J.N., Oetomo, H., \& Suprapto, M.H. $2013 . \quad$ Pengaruh Lingkungan Kelas Terhadap Sikap Siswa untuk Pelajaran Matematika. Humanitas, Vol. X No.1 Januari 2013

Slameto. 2003. Belajar dan Factor Faktor yang Mempengaruhinya. Jakarta: Rineka Cipta

Suryabrata. 2013. Psikologi Pendidikan. Jakarta: Raja Grafindo Persada

Tarmidi. 2006. Iklim kelas dan prestasi belajar (Skripsi, Universitas Sumatera Utara, 2006). http://repository.usu.ac.id/bitstrea m/123456789/1928/1/06010310.p df. Tanggal Akses 25 September 2013

Widoyoko, E.P. 2012. Teknik Penyusunan Instrumen Penelitian. Yogyakarta: Pustaka Pelajar 
